\section{Mindre vold etter psykose enn antatt}

Personer med en psykosediagnose er ikke mer kriminelle enn den generelle befolkning når behandlingen er kommet godt i gang.

Mennesker med psykoselidelser er blitt karakterisert som mer voldelige enn den generelle befolkningen over tid. En nylig publisert studie fra den norsk-danske TIPSstudiegruppen nyanserer denne stereotype oppfatningen (1). I studien har vi over ti år fulgt 178 personer som kom til behandling for førstegangsepisode av affektiv psykose i perioden 1997-2000 i Rogaland, Oslo og Roskilde. Deltakernes kontakt med rettsvesenet ble kartlagt $\mathrm{i}$ hele tiårsperioden, og ved tiårsoppfølgingen ble de spurt om voldsbruk og trusler om vold.

Vi fant at forekomsten av kriminell atferd faller gradvis etter oppstart av behandling. Ti år etter første kontakt med helsevesenet hadde personer med en psykosediagnose ikke mer kontakt med rettsvesenet enn den generelle befolkningen ( $2 \%)$. Ved tiårsoppfølgingen rapporterte $15 \%$ av deltakere at de hadde brukt vold eller truet med vold det siste året. Dette er 50\% færre enn det som rapporteres for personer med ubehandlet psykose. Betydelig bruk av rusmidler viste seg å være en alvorlig risikofaktor for vold hos personer med en psykosediagnose, også lenge etter at behandling var startet opp. Pasienter med mye hallusinasjoner og/eller vrangforestillinger som også brukte mye rusmidler hadde økt langtidsrisiko for farlig atferd, men dette gjaldt et lite mindretall av deltakerne.

Vi mener oppsøkende behandling med mål om å oppnå rask symptomreduksjon og lavere rusmiddelforbruk vil kunne føre til lavere risiko for voldelig atferd hos denne undergruppen av pasienter med psykosediagnose.

\section{Johannes Langeveld}

Regionalt senter for klinisk psykoseforskning ved Helse Vest

Stavanger universitetssjukehus

\section{Litteratur}

1. Langeveld J, Bjørkly S, Auestad B et al. Treatment and violent behavior in persons with first episode psychosis during a 10-year prospective follow-up study. Schizophr Res 2014; 156: 272-6.

\title{
Høyere overlevelse hos barn i Mosambik
}

\author{
Det er en sammenheng mellom økt antall helsearbeidere og redusert \\ barnedødelighet i Mosambik. Det viser en ny studie.
}

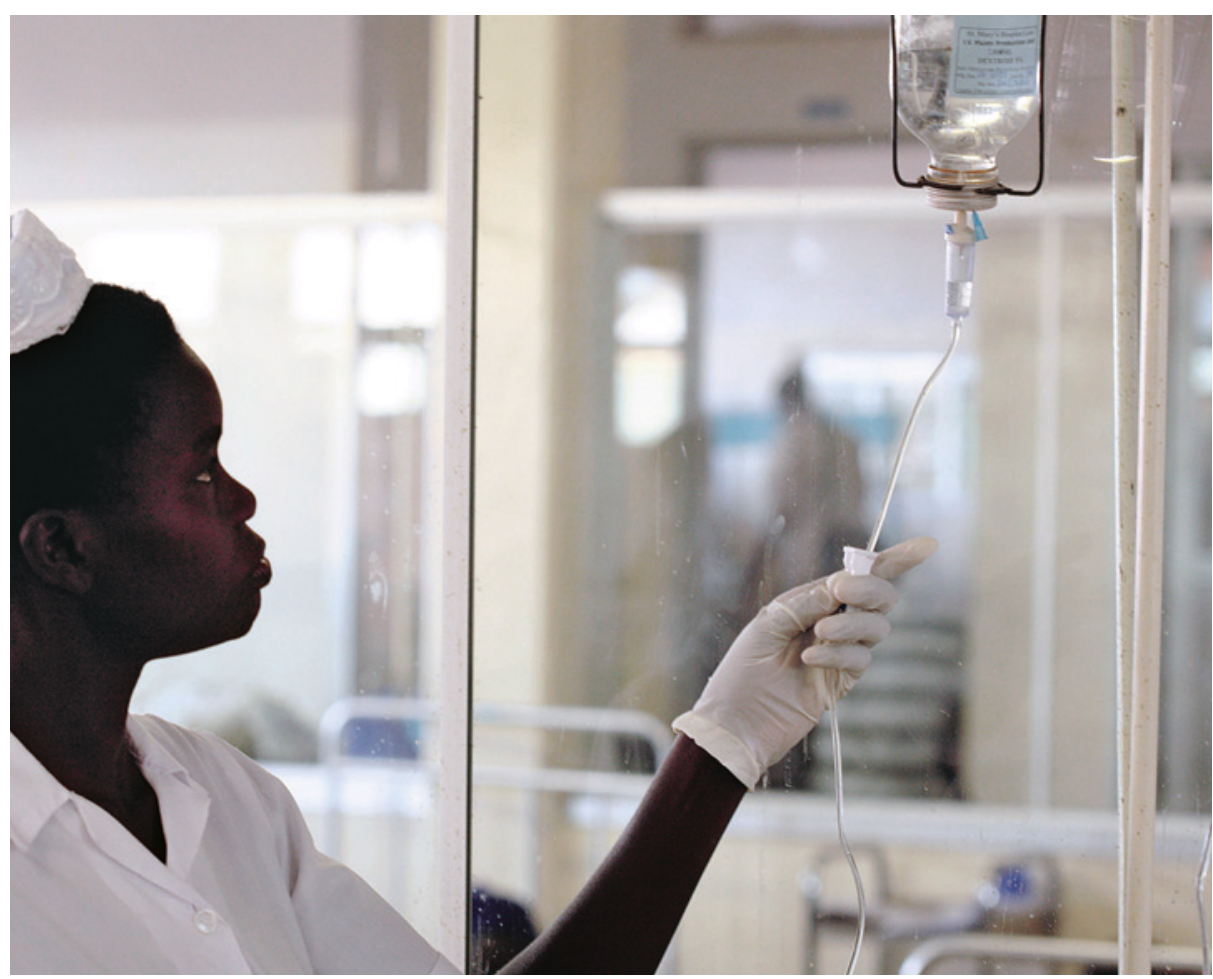

Illustrasjonsfoto: Sciencephoto/NTB scanpix

I en longitudinell studie er assosiasjonen mellom endringer i helsevesenet og barnedødelighet i Mosambik undersøkt (1). Dødeligheten i aldersgruppene $0-4$ år, 0-1 år og 0-1 måned ble estimert for hvert år i perioden 2000-10 ut fra datasett for over 58000 barn.

Estimert dødelighet for barn under fem år i Mosambik falt fra 166,6 per 1000 levendefødte $(95 \%$ KI 162,2-171,2) i 2000 til 93,7 (95\% KI 87,9-100,0) i 2010. I provinsen med størst reduksjon falt dødeligheten med $11,1 \%$ årlig, mot 1,9 \% årlig i provinsen med lavest reduksjon.

Ti flere helsearbeidere per 100000 innbyggere var assosiert med $5,8 \%$ reduksjon i dødelighet hos barn under fem år og 8,1\% reduksjon i dødelighet hos nyfødte. $\emptyset \mathrm{kt}$ andel fødsler ved helseinstitusjon var også assosiert med redusert dødelighet hos barn under fem år, mens økt antall innbyggere per helseinstitusjon var assosiert med økt dødelighet.

- Det denne undersøkelsen i klartekst sier, er at helhetlig styrking av helsesystemet, det vil si både bedre helsetjenester, større bruk av helsetjenester, flere helsearbeidere og bedre finansiering, faktisk har en klar effekt på overlevelsen, sier professor Johanne Sundby ved Avdeling for samfunnsmedisin ved Universitetet i Oslo.

- Resultatene viser at helsetjenesten må styrkes på sikt, og at universell helsedekning og rettferdighet blir sentrale variabler å se etter, fortsetter hun.

- Studien viser også hvor viktig det er med gode helseinformasjonssystemer, noe som ikke kan understrekes nok. Slike systemer må brukes for å oppdage og forklare ulikhet i helse, sier Sundby.

\section{Matilde Risopatron Berg}

Sykehuset Innlandet, Hamar

\section{Litteratur}

1. Fernandes QF, Wagenaar BH, Anselmi L et al. Effects of health-system strengthening on under5 , infant, and neonatal mortality: 11-year provincial-level time-series analyses in Mozambique. Lancet Glob Health 2014; 2: e468-77. 